\title{
"Governance" em Tempo de Pandemia: Um Enquadramento Filosófico
}

\author{
Orlando Coutinho* \\ * Universidade do Minho, Portugal; orlando.coutinho@sapo.pt
}

\begin{abstract}
Resumo
O modo como um vírus desconhecido passou de um caso local ao global, assumindo o contorno pandémico, causou na vida de todos os seres humanos mudanças significativas. Em primeiro lugar, por isso mesmo, o ser desconhecido, depois porque atrás do desconhecimento vem a desconfiança e o medo. Ora, estes ingredientes, são - no espaço político-social - substância para os maiores fatores de ação e decisão dos atores do poder. Estivemos em contexto de guerra, como alguns afirmaram? Foi um confinamento, global e tão prolongado, efetivamente necessário? Decretar o Estado de emergência era imprescindível? As medidas de exceção foram proporcionais? E serão reversíveis? Este artigo visa, à luz das ideias de vários autores habituados a pensar múnus filosófico político de contextos sanitários, de exceção e de controlo político do Estado, diante de questões de saúde pública e não só, percecionar o "estado da arte" no modo de governo das democracias ocidentais, em primeira linha, mas sobrevoando outras geografias e sistemas já que o vírus assumiu contornos globais. E, por vias das medidas concretas, politicamente adotadas, pelos diferentes atores políticos, que impactos reais elas tiveram na vida e funcionamento das instituições e na psicologia das pessoas individual ou socialmente consideradas.
\end{abstract}

Palavras-chave: Governance; Biopolítica; Psicopolítica; Exceção; Vigilância 


\begin{abstract}
The way in which an unknown virus has moved from a local to a global case, taking on a pandemic outline, has caused significant changes in the lives of all human beings. Firstly, for that reason, it is unknown, then because behind the ignorance comes mistrust and fear. Nowadays, these ingredients are - in the political-social space - substance for the biggest factors of action and decision of the actors of the power. Have we been in a war context, as some have said? Was confinement, global and so prolonged, really necessary? Was decreeing a state of emergency essential? Were the exception measures proportional? And are they reversible? This article aims, in the way of the ideas of several authors that thinking about the political philosophical role of health contexts, of exception state, and of political control of the State, in face of public health issues and not only, understand the "state of the art" in the way of governing western democracies, in the firstly, but flying over other geographies and systems as the virus has assumed global contours. And, by means of the concrete measures, politically adopted, by the different political actors, what real impacts they had on the life and the institutions working, and on the psychology of the persons individually or socially considered.
\end{abstract}

Keywords: Governance; Biopolitics; Psychopolitics; Exception; Surveillance

\title{
1. Introdução
}

O surgimento pandémico do coronavírus trouxe pela primeira vez, para o cenário político institucional do Globo, uma medida tão extrema quanto inédita: quase, se não todos os países, decretaram um recolher obrigatório das suas populações por um longo período de tempo.

Perante a desconhecida forma de como lidar com um vírus, ele mesmo desconhecido, pelas autoridades sanitárias e diante um contágio massivo sem que houvesse vacina ou tratamento eficaz convencionado, as interrogações sobre como agir, como proteger, como decidir, multiplicaram-se.

A propagação rápida e as mortes fulminantes geraram um "caos operandi" junto de decisores e de técnicos de saúde, estes últimos, ademais, na designada "frente de batalha". Foi, assim mesmo, declarado - um pouco por toda a parte - o Estado de Sítio, a medida com maior "gravitas política" na centralização do poder decisório seja ela em contexto democrático, ou não - com os responsáveis políticos falando mesmo em Guerra (Anjos, 2020).

Ante este cenário, que se prolongou entre três e quatro meses, como reagiram os responsáveis políticos? Que governance impuseram durante a dita calamidade? Como ficou o quadro político-institucional? E as ditas democracias, resistiram ou sofreram uma forte erosão? E a psicologia social das comunidades, em que estado ficou? 
O objetivo deste artigo é, a partir da convocação de reconhecidos autores na área filosófico-política, procurar estabelecer uma hermenêutica "pré e pós aparecimento do Covid-19", sobretudo na robustez das instituições governativas como um todo e, pelas suas ações ou omissões, que impactos daí sucederam sobretudo para os sistemas políticos democráticos, sobrevoando os restantes, e para as comunidades destinatárias das ditas iniciativas políticas em tempos de pandemia. Em cinco pontos que, para o efeito, se afiguram relevantes, procurar-se-á passar em temas como a bio e a psico política, os modelos de governação em contextos de exceção e se houve, ou não, uma tentação panóptica e punitiva.

\section{A psicopolítica sanitária: efeitos humanos}

O contexto sanitário da pandemia, trouxe, relativamente ao vírus, até então desconhecido, uma desconfiança acrescida relativamente à sua transmissão e possibilidades de contágio. De facto, os primeiros casos vindos a público eram aterradores quanto à sua propagação e consequências. Se, primeiramente e das informações vindas da China, onde, tudo indica, ter-se dado o primeiro foco epidémico, os casos relatados não registavam tamanho pânico na gestão da "nova crise" - a que alguns associaram teorias político-conspirativas - quando o coronavírus se "instalou" na Europa, as ondas de pavor foram evidentes. Com os média a adotarem como registo editorial quase em exclusivo a cobertura integral da evolução do fenómeno, não só do ponto de vista estatístico dos infetados, dos casos graves, dos óbitos, da gestão da salubridade pública em todo o seu processo, das decisões políticas e do "way of life" da população em geral, como mote para a compreensão social do fenómeno e eventual responsabilização dos focos de contágio, a verdade é que - com tamanha mediatização, um pouco por todo mundo - a ideia do medo, paulatinamente veio a instalar-se nas diferentes comunidades. Para o facto, os relatos vindos mormente de Itália e Espanha, onde a morte não era humanamente tratada, rasgando todas as convenções sociais na hora dos enterros adiados e sem despedidas da família (Bourgard, 2020), agravou-se o sentido de desvinculação com o próximo a que já se vinha assistindo por motivos de ordem económico-social (Chul Han, 2018). O que o filósofo coreano Byung-Chul Han nos traz à cogitação, não só em ensaios anteriores como em pensamentos "ao dia", é uma ideia de medo ao diferente, no caso ao infetado (Chul Han, 2020). A lógica de fechamento grupal, identitário ou até tribal, onde prosperam focos de maior pendor nacionalista emergiu e as medidas políticas que deixaram cair Schengen e outras restrições fronteiriças ainda que de apelo humanitário caíram por terra.

Passamos da "Psicopolítica" do "Big Data" que tenta controlar os passos todos (Chul Han, 2015), vista até com alguma simpatia, por setores mais comunitaristas, em época pandémica, se tal permitisse isolar infetados para evitar contágios, para a "Expulsão do Outro", o diferente o que pode estar doente:

A histeria com a saúde é, em última instância, a histeria com a produção. Mas destrói a verdadeira vitalidade. A proliferação do saudável é tão obs- 
cena como a proliferação da obesidade. É uma doença. Tem uma morbidez inerente. Quando se nega a morte em nome da vida, a própria vida torna-se algo destrutivo. Torna-se autodestrutiva. Confirma-se aqui uma vez mais a dialética da violência. (Chul Han, 2018, pág. 40)

A sociedade do medo a que alude Luc Ferry embrenhou-se - com os desafios eco-políticos em curso - em permanentes receios, face ao desconhecido (Nunes, 2019).

O Homem, enquanto sujeito ôntico e existencial, desconfia-se, estranha-se a si, ao outro e ao espaço físico em que habita, como um "estrangeiro" (Camus, 2015).

$\mathrm{O}$ vírus, como se nos apresentou, veio majorar todas estas angústias humanas permeabilizando uma incursão do biopoder e da sua eficácia na projeção dos mais variados comportamentos humanos.

Os técnicos de saúde face à impreparação política e à indecisão ante a novidade começaram a pilotar e o plano de voo passou a ser a interrupção do humano. O primeiro decreto foi o fim do toque. «Não cumprimenta se não com o cotovelo; não se abraça na morte; não se beija no namoro; não se acariciam os pais; não se visitam avós em lares; não se faz amor! (a não ser de modo esdruxulo)» (Diário de Notícias, 2020). Não, não e não! Proibir, restringir, limitar! O novo léxico estava encontrado. Escola à distância, teletrabalho, comércio on-line e videoconferências, passaram de filões a paradigma. A câmara do Big Brother entrou pelas casas adentro impondo, aos papéis sociais tecnologicamente reconfigurados, o fim da privacidade (Tavares, 2020). Ao interregno social, correspondeu a hiperbolização tecnológica. A economia, em geral, fechou; as relações de trabalho - a quem o conservou - mudaram; a escola reconfigurou-se (?!); os Homens distanciaram-se, independentemente dos seus contactos na rede.

A biopolítica (Focault, 2010) na forma como a descreveu o filósofo, atravessou as suas fronteiras. Muito mais do que a estatística clínica do controlo dos processos vitais do corpo social, - que também se revigorou na exclusividade do vírus - o biopoder selou-se entre médicos e políticos no compromisso da transmutação do novo "homo economicus" com a eficácia na proteção bio-humana da vida. Assim seria possível a paz social. Não se estranha, pois, que o xadrez diplomático tenha começado a jogar-se nos termos biopolíticos. As democracias europeias tardaram em respostas, pelo seu ritual multicomplexo e os dois blocos hegemónicos - Estados Unidos da América, de si redesenhado nos tempos hodiernos e China, apostada na construção de uma nova liderança geopolítica - digladiaram-se em diferentes tabuleiros. Os americanos - na incapacidade do controlo sanitário dos contágios - apostaram na retórica agressiva do "vírus chinês"; os chineses, acossados pela negação das informações iniciais, encaminharam-se na diplomacia da salubridade, espalhando, mundo a fora, ventiladores e outros equipamentos de prevenção e combate ao vírus.

No braço de ferro ocidente-oriente, parece ter havido, nas geodésicas políticas uma propensão à auscultação das filosofias orientais, como Nietzsche alvitrara (Nietzsche, 2019, pág. 30-31). 
O "Homem-Medo", face à incerteza, passa a dar sinais de confiar no ente superior, o Estado, face à desconfiança do si/outro e ao "vazio de Deus" no espaço público, que aderira à biopolítica do isolamento compulsivo a retalho, estando mesmo disposto a abdicar de liberdade, em função da segurança.

No fundo a criação de um hiato na vida com uma interrupção humana realizou-se à custa do medo e com uma sujeição, globalmente pacífica. A "caverna de Platão" era perentória: "não sair de casa"! O "inimigo invisível” desertificou as cidades, confinou terroristas e guerrilheiros, secundarizou outros pacientes. A saúde física foi glorificada - a mental, nem tanto - afinal, estávamos numa emergência psicopolítica. O novo higienismo trouxe - como merchandising - luvas, máscaras e álcool-gel e levou o poder político a um novo paradigma de ação: impedir - custe o que custar — novas infeções. Para tal só há uma certeza: da regra como (Estado de) Exceção.

\section{A exceção "Agambeniana" como contração da liberdade}

Quando o filósofo italiano Giorgio Agamben procurou debruçar-se amplamente sobre o Estado de Exceção, chegou a uma conclusão geral. A invocação de emergências para a aplicação de medidas inusuais por parte dos poderes públicos tornou-se frequente; mais, depois de aplicadas essas medidas em contextos específicos, dificilmente as mesmas se tornavam reversíveis e passavam a uma "aceitação geral" ganhando inercia própria que - ainda com eventuais resistências - acabavam por "normalizar-se". No seu tratado sobre o tema (Agamben, 2018), cuidou de detalhar a facilidade com que os governos avocavam a si a imprescindibilidade de suspender um conjunto de rituais consagrados numa determinada ordem constitucional, consensualizada, para - com caráter provisório - o dito ordenamento jurídico, contorcer-se e moldar-se, para - ao invés do obtestado - tornar-se recurso permanente e firmar-se como paradigma. Claro que os jugos, inabituais, tornam-se costumeiros e pesam de sobremaneira no quadro das democracias empurrando-as para fronteiras duvidosas: primeiro, no "modus vivendi" das populações que - sem se darem conta - acabam por incorporar, no quotidiano, de modo reflexivo mas não refletido, comportamentos em acordo com a excecionalidade subliminarmente imposta; segundo, porque a simetria democrática que reparte poderes e responsabilidades, tende a concentrar-se e a absolutizar-se. Da subsidiariedade, passa-se ao empoderamento do Estado, e o equilíbrio geral entre o Homem em si e a sua relação com o ente organizativo da comunidade dilui-se desprotegendo-o, sendo-lhe dito que essa desproteção, com o compromisso de uma pontualidade que acaba por se revelar constante, visa, exatamente, defender os seus interesses. As liberdades individuais são contraídas em nome de uma sensação de segurança e proteção. Desumaniza-se a vida social e a tabela axiológica de valores é substituída pela de Maslow "tout court". O provisório, o pontual, o excecional, tornou-se expediente comum do procedimento tecnicista governamental. Há o tremendismo, há a exceção e há a desregulamentação do ordenamento jurídico pactuado. 
Ao ser apresentado como uma guerra, o invisível inimigo coronavírus, foi o mote para o decretar do Estado de Exceção. Vejamos, neste ponto, os casos concretos do impacto desta ocorrência potestativa na vida comum das pessoas. Deixemos para o próximo, o "empoderamento do Estado".

Quando em Portugal o magistrado máximo do país, o Presidente da República, se escudou no termo "Guerra" para decretar o Estado de Emergência logo se referiu à necessidade de avocação central e excecional dos poderes do Estado na sede do governo para que a gestão da saúde pública fosse absolutamente eficaz (Petiz, 2020).

Por seu turno, o decreto do governo a regulamentar a dita exceção, impôs a contração de um conjunto significativo de liberdades individuais (Diário da República, 2020).

Vejamos algumas com detalhe e verifiquemos o comportamento da administração pública.

A liberdade de circulação. Foi das mais impactantes contrações à liberdade humana. O Homem enquanto ser social e relacional viu delimitada a sua circunferência de ação. A regra foi o confinamento que - para os casos ditos de especial vulnerabilidade - constituiu-se numa espécie de recolher obrigatório. Estavam previstas um leque variado de saídas e das circunstâncias das mesmas, mas o facto é que a regra passou a ser "recolha-se"! Atentemos a um dos casos que eventualmente merecia uma resistência mais veemente. Dizia o artigo quarto número um do dito decreto que "os maiores de setenta anos" só poderiam circular nas restritas circunstâncias definidas no número seguinte da lei em causa. Coloquemos as interpelações que se impõem num Estado Democrático: pode limitar-se a liberdade de circulação de uma pessoa em função da sua faixa etária? Mesmo que seja saudável, tenha tudo regularizado na sua relação comunal e tenha uma atitude irrepreensível no seu comportamento social? Não estará na esfera da sua liberdade individual decidir se quer ou não sujeitar-se a contrair um vírus ainda que tal possa vir a significar a sua morte? Não estará o Estado a adotar uma medida discriminatória e desproporcionada a alguém que por força da idade tem menos vindicação reivindicativa? Que consequências na saúde mental terá provocado esta medida? Ainda que sem expansões excessivas, foi dada voz pública a uma associação que se dedica à defesa dos interesses dos mais idosos. A Presidente foi taxativa: haverá impactos na saúde mental e física com este tipo de medidas. (SIC Notícias, 2020).

A proibição de visitas. Tanto em lares como em hospitais o contacto familiar foi fortemente restringido (Lusa, 2020). O sentimento de abandono a que ficaram votados aqueles que já estavam em situações de especial vulnerabilidade, agravou-se. Os rituais familiares, religiosos e comunitários, esvaíram-se. O "novo normal” impôs um afastamento do outro, por mais querido e próximo que fosse. Acabaram namoros e outras relações. Findou-se o toque e o afeto. 
O fim dos funerais? Outra das restrições draconianas impostas foi uma malha apertada a rituais antropológicos que nos colocam num patamar humano. Independentemente da sua expressão religiosa ou civil, o termo da vida é um cenário nela contida e as ligações afetivas e sociais que um determinado Homem teve na sua existência terrena, compreende uma reflexão própria que só os funerais comportam. A soma das limitações à liberdade individual implicaram a reconfiguração do luto sem direito a despedidas daqueles que - não estando infetados ou que a causa de morte tenha sido diversa do covid-19 ficaram sem um funeral condigno do código socio-humano vigente, como já anteriormente referido e citado. Será isto compaginável com um regime democrático?

As relações laborais. Foram outras que também sofreram perturbações evidentes. Obrigatoriedade de teletrabalho em todas as funções em que este sistema se adaptasse. Constituiu ou não uma invasão digital decretada na privacidade da casa? Alterou, ou não a disponibilidade do trabalhador - a braços com outras tarefas domésticas, acompanhamento dos filhos etc. - para o exercício da função? Horários, custos com internet, computadores e outros equipamentos digitais quem suportou? Desde o fim do direito à greve, à dispensa de trabalhadores com contratos precários ou sem vínculo, cortes salários e de prémios, o Estado de Exceção, mutilou o contratualismo social ligado aos direitos laborais, sendo que - nos entretantos - o próprio Estado chamou a si, o mais das vezes, os custos sociais imanentes. O líder da Igreja Católica pediu solidariedade (Moreira, 2020) a mesma que os seus subordinados não foram capazes de garantir (TVI, 2020).

A escola, digitalizada, também viu alicerces abalados que colocaram os mais indefesos economicamente sem acesso igual ao ensino (virtual) por falta de equipamentos suficientes no contexto familiar.

O direito ao trabalho e ao ensino não foi universal, só o "estritamente necessário para as funções vitais" que, com tal epiteto separou duas margens de cidadãos protegidos e os largados à sua sorte.

O uso da máscara. Primeiro facultativo, depois obrigatório em espaços fechados até ao ensaio no espaço público (Ferreira, 2020). Quem ousa tirar, desafia a autoridade. Passou-se à era da importância na expressão do olhar e do "Homem sem rosto". Da ida contestação europeia ao véu islâmico, ao ocaso total do rosto - agora só visível nas redes sociais - foi um passo que tolhe a identidade pela diferença e torna o mar de mascarados num só. Parte da liberdade esvaiu-se e no regresso à propalada "nova normalidade" algumas exceções passaram a regra. O medo do próximo tolhe a liberdade e esta readquiriu nova e mais modesta semântica quase que antónima à sua essência.

O Estado revelou a sua supremacia e a sua presença tornou-se asfixiante. 


\section{O regresso a Foucault: vigiar e punir}

Depois da consolidação bio e psicopolítica, o Estado como grande organizador da comunidade foi chamado à primeira linha das respostas emergentes. Sem complexos e de um modo geral - como adiante veremos - deitou mão da autoridade e poder possível por câmbio das respostas socioeconómicas que lhe reclamavam.

À ordem do confinamento compulsivo, a marcha policial nas ruas era real e para lá dos avisos de sensibilização, a semiótica comunicacional implícita era inequívoca: “estamos cá para pôr na ordem quem incumprir o novo ordenamento jurídico". Estava dado o mote Foucaultiano do "Vigiar e Punir".

O controlo sanitário ganhou vestes políticas. A comunicação diária e intrusiva das estatísticas de um luto impedido de vivenciar era feita não só pelas autoridades técnicas de saúde: ao lado, uma Ministra, um Secretário de Estado, um assessor, um contratado político. Era preciso vencer a batalha da comunicação político-sanitária para empreender o restante, ainda que - violando a mais elementar proteção individual de dados - se colocasse, "misericordiamente" ao dispor, uma aplicação digital para controlar remotamente infetados e não infetados que veio a designar-se stayaway covid. Se não chegasse o regresso aos "bufos" valia igualmente numa coação mental do "polícia de si próprio", como tantas vezes se ouviu na esfera pública.

No restante, estava bom de ver, a abertura do leque da ação governativa com assentimento e proposta da oposição dita maior. Em Portugal, o parlamento prescindiu de ver o governo a prestar-lhe contas (Jornal de Notícias, 2020) ao mesmo tempo que findavam os concursos internacionais assim como as certezas da probidade dos ajustes diretos (Varzim, 2020). O sistema de justiça abrandou com o confinamento e - quando nas mãos do poder político - ficou sujeito à arbitrariedade (RTP, 2020). Calava-se a oposição em sede parlamentar (Lusa, 2020), distribuía-se comida nas ruas aos "novos pobres" (SIC Notícias, 2020). Se ao povo desse trejeito peticionário diminuía-se-lhe as intenções, (Lusa, 2020) ou se quisesse agigantar-se, ainda que no burgo, estaria vedado, afinal tudo requer enquadramento institucional (Lusa, 2020).

Poder-se-ia interpretar um laivo crítico anti-sistémico, já que se põe a nu as fragilidades dos partidos que suportam o governo e os que estão na oposição; mas não, são tão só descrições documentadas das iniciativas dos atores políticos no cenário pandémico constituindo-se, por isso e tão no conjunto, a real governança da crise.

Temos, pois, sem hiperbolismos, uma evidente degradação democrática, com o sistema de checks-and-balances diminuído nas sedes democráticas de controlo. Um reforço do poder do governo, a diminuição do papel parlamentar, a pausa na justiça, a tentativa - posteriormente vetada - da petição popular e uma dependência económico-governativa da imprensa sujeita a uma diminuição de receitas sem precedentes no setor da publicidade.

O exemplo de Portugal, que se multiplicou um pouco por outros países europeus, com isto, não viu o seu sistema democrático posto em causa, mas diminuiu-lhe a consistência, aumentou-lhe o risco e colocou-o sob stress, abrindo alas a movimentos refundadores do regime que clamam já por uma IV República, não se afigurando 
que seja, pelas propostas iniciais, em moldes tidos como humanístico democráticos (Banha, 2020).

\section{Sinais vitais da democracia: reminiscências de Riemen}

A democracia pela sua natureza frágil é um sistema permanentemente à prova. Se num regime totalitário a condução de um pensamento único é condição, "sine qua non", para (se) sobreviver, já a tolerância implícita na discussão de diferentes modelos, como é permitido em contexto democrático, coloca em cima da mesa uma certa perigosidade, na exata medida em que o "palco", para a promoção e atuação de paradigmas totalitários, não está vedado. O cantor e compositor português Sérgio Godinho, numa das suas interpretações, dizia que «o fascismo é uma minhoca que se infiltra na maçã; ou vem com botas cardadas ou com pezinhos de lã». Por seu turno, Rob Riemen, filósofo e ensaísta holandês, em "O Eterno Retorno do Fascismo" e em "Nobreza de Espírito Um Ideal Esquecido", identifica os sintomas e o "modus operandi" que caracteriza o arquétipo fascista. Fá-lo sempre em contexto conceptual, apontando caminhos de como se mostrará, num alerta bem presente e premente, que não devemos ignorar.

De olhos postos na atualidade, com o "advento" do coronavírus, o estado de espírito ocidental revela, ou não, sintomas que devem colocar as democracias em alerta? Socorramo-nos deste filósofo que defende que o fascismo é, igualmente um vírus que nunca desaparece - e bebe na fonte de outros filósofos - para cotejar se o "modus operandi" adotado na "governance" deste vírus, se assemelha ao que o autor sustenta ser um aferível método procedimental para a exploração e implementação de medidas totalitárias.

Em “O Eterno Retorno do Fascismo" Riemen invoca Albert Camus que disse não aos seus amigos quando lhe pediram para pôr de lado a moral em nome da política. E refere-se, também, a Leone Ginzburg que recusa colaborar com o Fascismo, optando por morrer sob tortura. No último capítulo, Coragem, do livro Nobreza de Espírito Um Ideal Esquecido, o que se terá passado num diálogo entre este personagem $\mathrm{e}$ um ex - colega de Universidade, onde o último - bem ao jeito das elites atuais - remata "um mundo melhor" como sendo aquele em que nos adaptamos ao que é regulado, independentemente dos valores que lhe subjazem. A liberdade de pensamento individual e a defesa de um complexo mínimo de valores humanísticos fica secundarizada em favor de um bem-estar egoico. Refere-se ainda a Thomas Mann nos anos 20 do século passado - onde aliás se vivenciou um cenário semelhante com a designada gripe espanhola - dizia que só os valores do Humanismo podiam proteger a civilização da barbárie e do fundamentalismo. Ou seja, as preocupações são evidentes, segundo o autor, quanto à vulnerabilidade do espírito humano para acatar ideais extremistas caso não haja uma defesa firme da democracia. Fala mesmo em métodos cristalinos de implementação, que deveremos observar hermeneuticamente com as medidas ditas de exceção que agora se tomaram. 
As causas. Rieman fala essencialmente três causas que abrem alas para o "retorno do fascismo", a saber: niilismo; degradação económica; fatores de insegurança. Estarão ou não presentes estas ditas "causas" desde o aparecimento e até antes do covid-19? Se quanto ao sentimento de insegurança causado pelo medo de contágio é hoje comum, a degradação económica provocada pelo confinamento forçado e o fecho compulsivo de vários negócios também não oferecerá dúvidas tais são as diversas previsões de alterações abruptas de indicadores afirmadas pelas instituições europeias, como a queda vertiginosa do PIB e a subida galopante do desemprego. O niilismo e o sentimento de desapego às causas e rituais mais humanistas também se agravou com os exemplos dados relativamente aos funerais, visitas a lares etc..

O móbil. No ponto primeiro aquando da abordagem psicopolítica do fenómeno, falamos na "Expulsão do Outro". Riemen aborda-o igualmente nesta separação de campos para que se cria a margem de batalha com laivos identitários através de uma dialética em que entra o nós e o outro, o estranho que se torna inimigo. Se na abordagem que adota tem em conta o contexto histórico como o judaísmo fazendo-o álibi do Nazismo e nos anos mais recentes o Islão como fonte do terrorismo, agora o móbil é retoricamente invisível mas apresenta-se de forma clara: o vírus. É ele que será instrumentalizável para quem vê nesta oportunidade histórica um modo de fragilizar o sistema de governo democrático.

Instrumentos. A apologética totalitarista usa, nas palavras do autor uma comunicação social acrítica e reprodutora de sound-bites para uma dialética falsa - vulgo fake news - onde fomenta por via de slogans fáceis e intuitivos o ódio, a inveja, o ressentimento e outros ingredientes que servem os fins em vista. No caso, quantas vezes não ouvimos o "vírus chinês" como slogan apelativo? Visava, ou não, a criação de um clima de ressentimento face a um regime que não publicava dados? E quantas vezes saíram, para a imprensa menos avisada, informações incorretas vindas de instituições oficiais que depois de multiplicaram em desculpas? Enfim, a instrumentalização do medo, ou a falta de rigor informativo como forma de proteção do poder, tem sido recorrente.

Público-alvo. Há, neste particular, um ligeiro desvio face ao identificado pelo filósofo que põe os jovens como um recurso fácil do populismo extremista. No caso da pandemia, é - precisamente - esta faixa etária a que mais vem resistindo ao discurso oficial e às medidas restritivas implementadas pela governação. São tidos como os mais "corajosos" e que rasgam a tentativa de institucionalização de um novo paradigma de isolamento social. Convivem, fazem festas e não se dispõem a abdicar da sua liberdade. No entanto quando Riemen aponta para as pessoas em dificuldade, estas sim, sejam quais forem as dificuldades que aí venham e já se identificaram várias, poderão ser um alvo mais permeável a discursos que apontam à democracia 
como modelo impeditivo de uma eficácia maior na estabilização e segurança dos novos processos sociais.

O crescimento da extrema-direita. A literatura em que Riemen faz a sua apologética já tem uns anos, contudo de presságio verificável. De facto, países como a França a Itália, a Alemanha, viram as forças políticas da direita radical a crescer. A Península Ibérica que parecia a salvo desta (re)emergência teve em Santiago Abascal em Espanha e André Ventura em Portugal representações parlamentares validadas e crescimentos auspiciosos aos seus interesses nos estudos de opinião.

A energia do combate. O reforço dos valores judaico-cristãos é mencionado pelo filósofo como o mote da resistência democrática a estas novas incursões da extrema-direita, que já vinha a fazer o seu caminho e que parece consolidar-se no contexto pandémico. A resistência ao facilitismo material, i.e., à corrupção moral é apontada como linha orientadora fundamental de modo a fazer colapsar o discurso oportunista de quem faz da erosão democrática uma aposta. Faz menção à ideia de uma Europa Unida, o que no contexto atual, com esforço, foi parcialmente conseguido com pacotes de ajuda económica aos países, mas sem a componente identitária e política que se adivinha no discurso do autor. Pensa, também, ser necessário um maior escrutínio à comunicação social; se é ela que informa e monitoriza - um papel fundamental na democracia, aquilo que é o direito à informação rigorosa, afigura-se importante que os órgãos de regulação sejam mais fiscalizadores. Por fim, ouvir quem está habitado a pensar. Ver os sinais dados pelos intelectuais e pensadores dos fenómenos democráticos é absolutamente decisivo.

\section{Geopolítica ou a loucura "Lévyana"}

Bernard-Henri Lévy no seu mais recente ensaio sobre o contexto do vírus reserva, no quinto capítulo, intitulado "O adeus ao mundo?", uma importante reflexão sobre o cenário geopolítico internacional e as diferentes reações do poder institucionalizado em regimes democráticos e outros, dos quais já se perdeu, por assim dizer, a identificação com tais valores. Com olhar atento, avisado e crítico, descreve comportamentos institucionais e relações diplomáticas e recolhe as consequências das incursões governativas nas áreas que afetam a cidadania. Vejamos, na titulação do próprio, "este vírus que nos enlouquece", no panorama internacional de diversas geografias.

Os Estados Unidos da América revelaram uma ausência de estratégia face ao inesperado vírus. À errância das primeiras manifestações, procurou um inimigo. Elegeu primeiro a China e depois a Organização Mundial da Saúde. Trump batizou o covid-19 como o "vírus chinês" e cortou o financiamento americano à subsidiária da ONU. Cerrou fileiras e fronteiras, usando máscara dizendo-a não obrigatória.

A China ficou envolta num manto de suspeição internacional devido às dúvidas informativas do regime. Muitos foram os que criticaram o esconder do problema na sua fase inicial e a mão de ferro usada à posterior com as suas populações, sobretudo 
no aproveitar do enredo para calar definitivamente Hong-Kong. Usou equipamentos e meios humanos enviados a outros países como charme diplomático numa tentativa de minimizar a retórica americana do "vírus chinês".

A Turquia ficou com a "rédea solta". Curdos e refugiados foram tratados com mão de ferro. As passeatas nas águas internacionais cipriotas eram uma pequena afronta e continuava a jogar as suas peças de xadrez na Somália e na Líbia. Apertou o controlo religioso transformando Igrejas em Mesquitas como o caso de Santa Sofia. Consolidou o poder.

Israel aumentava os colonatos, parou a justiça com as investigações ao Primeiro-ministro.

A Rússia cercava a Ucrânia - não contente com a anexação da Crimeia - e Putin, não deixou créditos por mãos alheias: aos opositores, serviu - literalmente - veneno.

A União Europeia tentou resistir com o eixo franco-alemão a aprovar fluxos de liquidez na economia procurando, com isso minimizar os efeitos antidemocráticos pungentes.

Outros exemplos foram dados pelo filósofo mas - com especificidades próprias, embora a salvo nas mesmas conclusões - pode dizer-se que, apesar da resistência europeia, o primeiro mundo, de modo corporativista descartou os refugiados e os precários do terceiro mundo numa falsa solidariedade humana. Os dislates prepotentes dos diversos países com propensão autoritária, não só continuaram como agravaram, com a ténue aparência de que o mundo mudara somente porque tinha deixado de ser opção editorial.

Lévy termina de forma cáustica a sua reflexão:

«Um mundo de donos de cães, quer dizer, de donos que são cães e se comportam como cães, uma humanidade que só tem direito a ladrar quando lhe lembram que é feita de homens, a gemer quando apanha um vírus e a latir quando o senhor Corona, nosso rei, lhe vier dar uma lição como se dá a ração ou uma tareia. (...) Não é bela a vida?» (Lévy, 2020)

Será, pois que haverá solução?

\section{Conclusão}

Pode concluir-se, face ao até aqui aduzido, que o sistema democrático sofreu, com a pandemia, fortes impactos erosivos do seu paradigma axiológico-institucional.

O reforço da autoridade do Estado com o empoderamento dos governos em gestão foi uma evidência como se constatou no ponto três. A diminuição dos mecanismos de controlo e fiscalização dos atos governativos operou-se sem grandes oposições, ou até mesmo com a ajuda de quem - em democracia - se aponta como alternativa. A este reforço do poder do Estado, correspondeu uma contração das liberdades individuais e coletivas, as respostas sociais foram, muitas das vezes, tímidas, errantes, ou inoperantes. As relações laborais alteraram-se profundamente com a fragilização de 
direitos e a desregulamentação ou a passagem para paradigmas, como o digital em que o espaço legislativo parece ir-se fazendo com o decurso das novas práticas. Mas quando chamado a responder, o Estado, trocou as demandas surgidas nos apoios sociais e à economia por um reforço claro da sua autoridade e poder prolongando de forma excessiva o Estado de Exceção Agambeniano que aparece a papel químico como o descreve o autor: duradoiro e paradigma técnico da governação hodierna. Contudo, a competitividade antiética nas relações interestaduais trouxe de novo à liça o problema das "mãos sujas" tão bem romanceado por Sartre. Retenção de equipamentos, medicamentos entre outras ações altamente contestáveis no relacionamento diplomático internacional parecem ter colocado na ordem do dia a dualidade Weberiana da "convicção e responsabilidade".

Robusteceu-se a Biopolítica e a ambição panóptica do Estado confinando as populações ao ponto da institucionalização do medo ao próximo e do contacto mínimo com o outro.

Perdeu-se o toque, a imagem, os rituais e os afetos: aumentaram-se as distâncias humanas.

Será este o "novo normal" de que tanto se fala? Ou ainda haverá esperança na recuperação do paradigma vivencial anterior? A ver vamos, como as forças político-sociais reagem nos tempos que aí vêm.

Data de receção: 10/09/2020

Data de aprovação: 12/11/2020

\section{Referências}

Aganben, G. (2018). Estado de Exceção. Lisboa: Edições 70.

Anjos, L. (20202). Covid19: Emmanuel Macron diz que a França está em guerra. RFI. Disponível em: <https://www.rfi.fr/pt/fran\%C3\%A7a/20200316-covid19-macron-diz-que-a-fran\%C3\%A7a-est\%C3\%A1-em-guerra $>$.

Banha, A.T. (2020). Ventura. O candidato antissistema que quer "Quarta República”. Jornal $i$. Disponível em: <https://ionline.sapo.pt/artigo/687737/ventura-o-candidato-antissistema-que-quer-uma-quarta-rep-blica-?seccao=Portugal $>$.

Bourgard, J. (2020). Morte sem adeus. Como os funerais de Covid-19 transformam o luto. Rádio Renascença. Disponível em: https://rr.sapo.pt/2020/04/18/reportagem/morte-sem-adeus-como-os-funerais-de-covid-19-transformam-o-luto/video/237441/

Camus, A. (2015). O Estrangeiro. Porto: Porto Editora.

Chul Han, B. (2018). A Expulsão do Outro. Lisboa: Relógio D’Água Editores.

Chul Han, B. (2018). O coronavírus de hoje e o mundo de amanhã, segundo o filósofo Byung-Chul Han. El País. Disponível em: <https://brasil.elpais.com/ideas/2020-03-22/o-coronavirus-de-hoje-e-o-mundo-de-amanha-segundo-o-filosofo-byung-chul-han. html>.

Chul Han, B. (2018). Psicopolítica - Neoliberalismo e novas técnicas de poder. Lisboa: Relógio D'Água Editores. 
Diário de Notícias. (2020). DGS do Canadá recomenda o uso de máscara durante o sexo. E nada de beijos. Diário de Notícias. Disponível em: <https://www.dn.pt/mundo/ dgs-do-canada-recomenda-o-uso-de-mascara-durante-o-sexo-e-nada-de-beijos-12602157.html>.

Diário da República. (2020). Decreto n. ${ }^{\circ}$ 2-A/2020 Regulamenta a aplicação do estado de emergência decretado pelo Presidente da República. Diário da República n. ${ }^{\circ}$ 57/2020, $1^{\circ}$ Suplemento, Série I de 2020-03-20. Disponível em: <https://www.portugal.gov.pt/ download-ficheiros/ficheiro.aspx? $v=3 f 8 e 87 a 6-3 c f 1-4 d 0 c-b 5 e e-72225 a 73 c d 4 f>$.

Ferreira, R. (2020). Uso de máscara na rua é obrigatório a partir de hoje na Madeira. Diário de Notícias. Disponível em: <https://www.dnoticias.pt/2020/8/1/69271-uso-de-mascara-na-rua-e-obrigatorio-a-partir-de-hoje-na-madeira $>$.

Focault, M. (2010). Nascimento da Biopolítica. Lisboa: Edições 70.

Jornal de Notícias. (2020). Aprovado o fim dos debates quinzenais. Jornal de Notícias. Disponível em: <https://www.jn.pt/nacional/aprovado-o-fim-dos-debates-quinzenais-12459198.html>.

Lévy, B-H. (2020). Este Vírus Que Nos Enlouquece. Lisboa: Guerra \& Paz.

Lusa, A. (2020). Covid-19: proibição de visitas a lares será "repensada" depois de haver regras de segurança. Público. Disponível em: <https://www.publico.pt/2020/05/03/sociedade/noticia/covid19-proibicao-visitas-lares-sera-repensada-haver-regras-seguranca-1914930>.

Lusa, A. (2020). Joacine "chocada" por não poder intervir na cerimónia do 25 de Abril. SIC Notícias. Disponível em: https://sicnoticias.pt/pais/2020-04-22-Joacine-chocada-por-nao-poder-intervir-na-cerimonia-do-25-de-Abril

Lusa, A. (2020). Petições passam a precisar de 10.000 assinaturas para serem discutidas em plenário. Visão. Disponível em: <https:/visao.sapo.pt/atualidade/politica/ 2020-07-23-peticoes-passam-a-precisar-de-10-000-assinaturas-para-serem-discutidas-em-plenario/>.

Lusa, A. (2020). CDS e PAN acusam PSD de querer mudar a lei eleitoral autárquica devido a Rui Moreira. Observador. Disponível em: <https://observador.pt/2020/07/10/cds-e-pan-acusam-psd-de-querer-alterar-lei-eleitoral-autarquica-devido-a-rui-moreira/>.

Moreira, S. F. (2020). Papa Francisco: "Uma empresa que despede para se salvar, não é solução”. Rádio Renascença. Disponível em: <https://rr.sapo.pt/2020/03/23/religiao/ papa-francisco-uma-empresa-que-despede-para-se-salvar-nao-e-solucao/noti$\mathrm{cia} / 186403 />$.

Nietzsche, F. (2019). O Anticristo (pp. 30-31). Lisboa: Edições 70.

Nunes, B. (2019). Luc Ferry: como alcançar a serenidade na sociedade do medo? Fronteira do Pensamento. Disponível em: <https://www.fronteiras.com/entrevistas/luc-ferry-serenidade-na-sociedade-do-medo $>$.

Petiz, J. (2020). Marcelo decreta Estado de Emergência. "Isto é uma Guerra. Temos de estar unidos. Dinheiro Vivo. Disponível em: <https://www.dinheirovivo.pt/economia/marcelo-decreta-estado-de-emergencia-isto-e-uma-guerra-temos-de-estar-unidos/ $>$. 
RTP. (2020). Procuradoria Europeia. Governo deu vitória a segundo classificado em concurso. RTP. Disponível em: <https://www.rtp.pt/noticias/pais/procuradoria-europeia-governo-deu-vitoria-a-segundo-classificado-de-concurso_v1246863>.

SIC Notícias. (2020). O impacto da pandemia nos mais idosos. SIC Notícias. Disponível em: $<$ https://sicnoticias.pt/especiais/coronavirus/2020-08-23-O-impacto-da-pandemia-nos-mais-idosos $>$.

SIC Notícias. (2020). Presidente distribuiu refeições a sem-abrigo. SIC Notícias. Disponível em: <https://sicnoticias.pt/especiais/coronavirus/2020-04-25-Presidente-distribuiu-refeicoes-a-sem-abrigo $>$.

Tavares, R. Sobre a Covid - 19 e o fim da privacidade. TSF. <Disponível em: https://www.tsf. pt/opiniao/sobre-o-covid-19-e-o-fim-da-privacidade-12061785.html>.

TVI. (2020). Santuário de Fátima prepara-se para despedimentos depois de três anos de prejuízos. TVI. Disponível em: <https://tvi24.iol.pt/videos/economia/santuario-de-fatima-prepara-se-para-despedimentos-depois-de-tres-anos-de-prejuizos/5f4e94da0cf2b3ce9d34c46d>.

Varzim, T. (2020). Tribunal de Contas quer travar ajustes diretos após emergência do Covid - 19. Eco. Disponível em: <https://eco.sapo.pt/2020/06/02/tribunal-de-contas-quer-travar-ajustes-diretos-apos-emergencia-do-covid-19/>.

\section{Sobre o autor}

orlando coutinho é Mestre em Filosofia Política pela Universidade do Minho. Membro associado do Observatório Político. Interesses de investigação: teoria política; sistemas de poder; partidos; ideologias. [https://orcid.org/0000-0001-7538-5652]

\section{About the author}

orlando coutinho is a Master in Political Philosophy from the University of Minho. Associate member of the Political Observatory. Research interests: political theory; power systems; parties; ideologies. [https://orcid.org/0000-0001-7538-5652] 